\title{
Aggregate indicator for quantification of sustainability to increase energy efficiency of industrial processes
}

\author{
Sabin Ioan Irimie $^{1 *}$, Dragoș Ștefan Roibu ${ }^{2}$, and Maria Oana Jurca ${ }^{3}$ \\ ${ }^{1}$ University of Petrosani, Department of Management and Industrial Engineering \\ ${ }^{2}$ Teletrans Bucharest \\ ${ }^{3}$ Petrosani School Sports Club
}

\begin{abstract}
The paper is motivated by the need to provide relevant synthetic indicators, on the basis of which decision makers can evaluate and compare, the extent to which the proposed projects fall within the goals of sustainable development - economic efficiency, environmental responsibility, social solidarity, circular economy, production and responsible consumption. The case study, introduced in the paper, refers to the real and optimal thermal energy balance, made for an installation for the preparation of asphalt mixtures. The approached example took into account the perspective of multiplication and modernization of asphalt mixture preparation stations. Based on the measurements, performed "on site" and the calculations performed, the values of some indicators referring to energy performance, economic efficiency and environmental impact were obtained. The obtained indicators were aggregated in a global indicator, useful for administrative decision makers.
\end{abstract}

\section{Introduction}

One of the priorities of Romania's economic consolidation refers to the development and modernization, in sustainable conditions, of the road structure elements. Achieving the aforementioned objectives requires a high consumption of various resources. The energy resource is necessary in most of the construction or remediation works of the road structure sections. The basic material for the works for the construction of the road structure is the asphalt mixture. The energy used in the production stages of the asphalt mixture reaches considerable values. [1]

Energy efficiency, through the consequences of increasing its value, determines the reduction of related consumption and other resources, responding to the desires of sustainable development focused on the formulation: maximizing benefits while minimizing resource consumption and safeguarding the biodiversity of the natural environment. [2]

\footnotetext{
1* Corresponding author: nibas8511@yahoo.com
} 
The aim of the paper is to propose an aggregate indicator for energy, economic and environmental quantification, to increase the energy efficiency of processes in a plant for the preparation of asphalt mixtures. Based on the experimental data established by carrying out an energy balance and the identification of energy inefficiencies, measures to reduce losses and capitalize on secondary thermal resources are proposed and quantified. The values obtained from the calculations are visualized in a radar diagram, based on which the energy used, the environmental impact, the energy cost and the specific energy consumption are aggregated as an indicator of sustainability. By comparing the indicator of the current state with that of the state obtained after the application of measures aimed at increasing energy efficiency, one can assess the evolution towards sustainability of the explored processes.

\section{Components of stay its preparation of asphalt mixtures [3]}

Aggregate household: compartmentalized aggregate storage boxes with elements from reinforced concrete, with concrete platform.

Asphalt preparation plant: hopper of aggregates with bunkers; collector conveyor belt for transporting aggregates in the dryer; silos for storage of limestone filler; "own filler" storage silo - the fraction of dust with a grain similarity to the limestone filler, resulting from the flue gas filtration battery discharged from the dryer.

Bitumen household: bitumen storage tanks, thermally insulated, provided with thermal oil coil for heating and maintaining the constant temperature of the bitumen; oil heater coil for heating the thermal oil, fitted in - a transportable container equipped with a gas burner; The bitumen household is located on a retention-type concrete platform.

Ancillary installations: inclined rotary drum dryer, equipped with a gas burner with high thermal capacity; flue gas filter battery discharged from the dryer; hot material elevator; site for final sorting of hot aggregates; hot filler dispenser; mixer; prepared mixer conveyor chip; bunkers storage prepared mix; cloudy dust storage container - the fraction of fine dust resulting from the flue gas filter from the dryer. When it is discharged into the container, it is moistened with water, forming a kind of mud; control cabin.

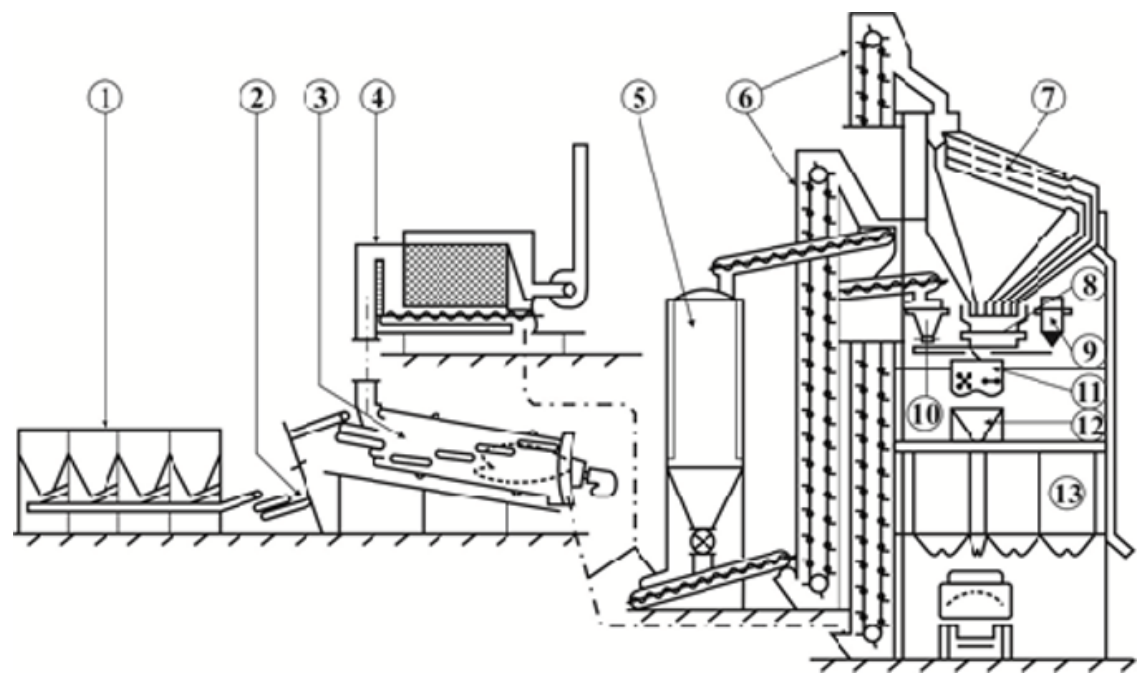

Fig. 1. Installation for batch production of hot asphalt mixtures:1. dispenser, 2. conveyor, 3. dryer, 4. dust remover, 5. vertical container, 6. bucket elevator, 7. separator screen, 8. aggregate dispenser, 9. bitumen dispenser, 10. filler dispenser, 11. batch mixer, 12. chip, 13. silo for storing the mixture.

The main scheme of composition and operation of an installation for the production of hot asphalt mixtures is presented in Figure 1. 
The performance of asphalt mixing plants is essentially determined by the quality and accuracy of the dosing of the components, as well as by the quality and duration of the mixing. Also, the temperature of the material in the various processing phases has a decisive role on the quality of the mixture.

During the technological process of preparation of asphalt mixtures, a series of non conformities may occur, the probable cause of which is specified in Table 1 .

Table 1. Possible non - conformities.

\begin{tabular}{|c|c|c|}
\hline $\begin{array}{l}\text { Name of the } \\
\text { procedure }\end{array}$ & $\begin{array}{l}\text { Name of non- } \\
\text { compliance }\end{array}$ & Cause \\
\hline Predosing aggregates & - Improper dosing & $\begin{array}{l}\text { - Dosing adjustment } \\
\text { - Defective dispensers } \\
\text { - Conveyor with incorrect / defective belt }\end{array}$ \\
\hline Drying aggregates & $\begin{array}{l}\text { - Low final temperature } \\
\text { - Improper combustion. } \\
\text { - Improper composition and } \\
\text { flow }\end{array}$ & $\begin{array}{l}\text { - Defective combustion system } \\
\text { - Improper fuel. } \\
\text { - Improper operation of the dust removal } \\
\text { system } \\
\text { - Improper construction / operation. of the dryer }\end{array}$ \\
\hline $\begin{array}{l}\text { Formal sorting of } \\
\text { aggregates }\end{array}$ & $\begin{array}{l}\text { - Improper granulometry / } \\
\text { kinds }\end{array}$ & $\begin{array}{l}\text { - Improper operation of sorting equipment } \\
\text { - Incorrect selection of sorting equipment }\end{array}$ \\
\hline $\begin{array}{l}\text { Final dosing of } \\
\text { aggregates, bitumen } \\
\text { and filler dosing } \\
\end{array}$ & $\begin{array}{l}\text { - Dosage not in accordance } \\
\text { with the prescription }\end{array}$ & $\begin{array}{l}\text { - Improper setting dispensers } \\
\text { - Fault in dispensers }\end{array}$ \\
\hline $\begin{array}{l}\text { Mixing mixture } \\
\text { composition }\end{array}$ & $\begin{array}{l}\text { - Improper homogeneity. } \\
\text { - Low temperature }\end{array}$ & $\begin{array}{l}\text { - Improper operation of mixer } \\
\text { - Improper isolation mixer }\end{array}$ \\
\hline
\end{tabular}

The aspects mentioned above emphasize the importance of the correct operation of the assembly and the careful and timely maintenance performed. Both the operation regime and the correctness of the operation, as well as the quality maintenance, have considerable effects on the value of the energy used. $[4,5]$

\section{Synthetic report on the quantitative results of the energy audit}

Based on the energy audit and the energy balances, real and optimal, the quantitative and qualitative performances related to the explored processes were quantified, for the real situation and for the optimal situation (achieved following the application of the necessary measures to increase the energy efficiency). The results obtained are highlighted in tables 2 and 3, and diagrams and synthetic situations (Figures 2 and 3) [6].

By adding energy entered, useful and lost, expressed in toe / year to obtain the following balance real annual complex the level of firm:

Table 2. Real annually complex balance.

\begin{tabular}{|c|c|c|c|c|c|}
\hline \multicolumn{2}{|c|}{$\begin{array}{c}\text { Input energy } \\
\text { [toe//year]/[\%] }\end{array}$} & \multicolumn{2}{c|}{$\begin{array}{c}\text { Useful energy } \\
\text { [toe/year]/[\%] }\end{array}$} & \multicolumn{2}{c|}{$\begin{array}{c}\text { Lost energy } \\
\text { [toe/year]/[\%] }\end{array}$} \\
\hline ELECTRIC & THERMAL & ELECTRIC & THERMAL & ELECTRIC & THERMAL \\
\hline $25.379 / 3.48$ & $703.606 / 96.52$ & $13.616 / 4.08$ & $320.089 / 95.92$ & $11.763 / 2.97$ & $383.517 / 97.03$ \\
\hline TOTAL ENERGY & \multicolumn{2}{|c|}{$\begin{array}{r}\text { TOTAL USEFUL } \\
\text { ENERGY }\end{array}$} & \multicolumn{2}{c|}{ TOTAL ENERGY LOST } \\
ENTERED & \multicolumn{2}{|c|}{$333.705 / 45.78$} & \multicolumn{3}{|c|}{$395.280 / 54.22$} \\
\hline $728.985 / 100$ & \multicolumn{2}{|r|}{} \\
\hline
\end{tabular}




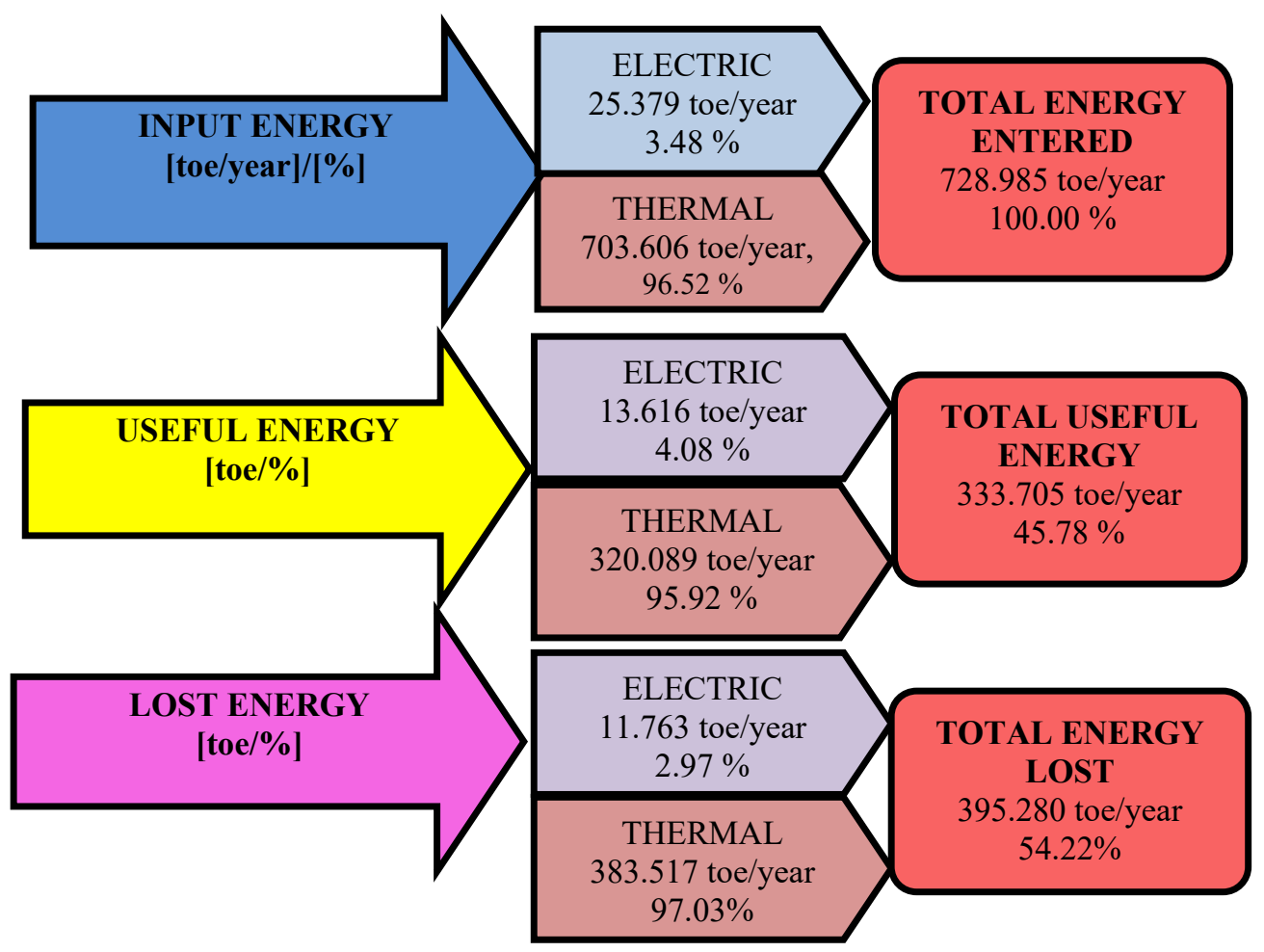

Fig. 2. Sankey diagram for the real complex annual energy balance.

\section{Located a summary on data obtained from achieving energy balance complex annual real:}

- Total energy used annually - $\mathrm{E}_{\text {total }}=728,985$ toe

- Total thermal energy used annually - Total thermal $\mathrm{E}=703,606$ toe $(96.52 \%)$

- Total electricity used annually $-\mathrm{E}_{\text {total electricity }}=25,379$ toe $(3.48 \%)$

- Total energy utilized useful annually $-\mathrm{E}_{\text {total useful }}=333,705$ toe $(45.78 \%)$

- Total energy efficiency $-\eta$ total $=45.78 \%$

- Total annual useful heat recovered - E Useful thermal total $=320.089$ toe $(95.92 \%$ of the total useful energy)

- Thermoenergetic efficiency - $\eta$ thermoen. $=45.49 \%$

- Total utilized useful annual electricity $-E_{\text {total useful electricity }}=13,616$ toe $(4.08 \%$ of total useful energy)

- Efficiency of electricity use - $\eta$ electroen. $=53.65 \%$

- Total energy lost annually - $\mathrm{E}_{\text {pierd.total }}=394280$ toe $(54.22 \%)$

- Total heat energy lost annually - It's heat loss. total $=383,517$ toe $(97.03 \%$ of total energy lost $)$

- Total electricity lost annually - It's electricity lost. total $=11,763$ toe $(2.97 \%$ of total energy lost $)$.

\section{Measures to reduce heat consumption}

1. The reduction of the material humidity from $5 \%$ to $3 \%$ is materialized in the reduction of the specific fuel consumption with: $\Delta \mathrm{C}_{\mathrm{sc}}=7,345 \cdot 10-3-6,044 \cdot 10-3=1,301$ $\cdot 10-3 \mathrm{~m}^{3} \mathrm{~N} / \mathrm{kg}$ material $=1,196 \cdot 10-6$ toe $/ \mathrm{kg}$ material At the hourly flow of material, the energy saving will be:

$$
\text { Gaze }_{\text {gas }}=195.15 \mathrm{~m}^{3}{ }_{\mathrm{N}} / \mathrm{h}
$$




$$
\mathrm{Te}_{\text {t.ep }}=0.179 \text { tep } / \mathrm{h}
$$

The measure imposes additional costs related to the arrangement of a canopy over the aggregate depot

The installation of an awning for the aggregate storage ensures the fulfillment of the following objectives:

- protection of aggregates from the effect of rainwater;

- a considerable reduction in the humidity of the aggregates resulting in a reduction in the fuel consumption required for drying.

2. Reducing shutdown times during the technological process_leads to the reduction of heat loss by accumulation. These losses are caused by the need to cool the dryer drum to avoid thermal stresses. The value of heat loss is estimated at:

$$
\Delta \mathrm{e}_{\text {accumulation }}=15960 \mathrm{MJ} / \mathrm{h}=414.72 \mathrm{~m}^{3} \mathrm{~N} / \mathrm{h}=0.381 \text { toe } / \mathrm{h}
$$

The measure does not impose additional costs.

3. Maintaining the bitumen temperature at $150{ }^{0} \mathrm{C}$ during dryer shutdown periods reduces energy consumption by:

$$
\mathrm{Te}_{\text {tep }} \cdot=1.78 \cdot 10^{-6} \text { toe } / \mathrm{kg} \text { bitumen }=0.02 \text { toe } / \mathrm{h}
$$

The measure does not impose additional costs.

TOTAL ACHIEVABLE SAVINGS - 0.579 toe / $\mathrm{h}$

NECESSARY INVESTMENTS - ASSESSED VALUE $=1,000,000$

The average annual operation duration of the asphalt mixture installation, resulting from statistics is 390 hours / year.

Considering 390 hours / year, the average annual operating time, results in annual savings, achievable due to the reduction of energy consumption, amounting to $0.579 \times 390$ $=225.81$ toe $/$ year.

Estimating the price of a toe at 1772 lei / toe results in an annual saving of $225.81 \mathrm{x}$ $1772=400135$ lei.

The payback period is estimated at $1,000,000 / 400135=2,499$ years $\approx 2.5$ years.

The implementation of the recommended measures leads to the reduction of energy losses and to the reduction of the environmental impact.

By adding energy entered, useful and lost, expressed in toe / year to obtain the following balance optimal annually complex the level of firm:

Table 3. Optimal annually complex balance.

\begin{tabular}{|c|c|c|c|c|c|}
\hline \multicolumn{2}{|c|}{$\begin{array}{c}\text { Input energy } \\
\text { [toe/year]/[\%] }\end{array}$} & \multicolumn{2}{c|}{$\begin{array}{c}\text { Useful energy } \\
\text { [toe/year]/[\%] }\end{array}$} & \multicolumn{2}{c|}{$\begin{array}{c}\text { Lost energy } \\
\text { [toe/year]/[\%] }\end{array}$} \\
\hline ELECTRIC & THERMAL & ELECTRIC & THERMAL & ELECTRIC & THERMAL \\
\hline $25.379 / 5.28$ & $454.931 / 94.72$ & $13.616 / 4.08$ & $320.089 / 95.92$ & $11.763 / 8.03$ & $134.842 / 91.97$ \\
\hline TOTAL ENERGY & \multicolumn{2}{|c|}{ TOTAL USEFUL } & TOTAL ENERGY LOST \\
ENTERED & \multicolumn{2}{|c|}{ ENERGY } & \multicolumn{2}{|c|}{$146.605 / 30.52$} \\
\hline $480.31 / 100$ & \multicolumn{2}{|c|}{$333.705 / 69.48$} & \multicolumn{3}{|c|}{} \\
\hline
\end{tabular}




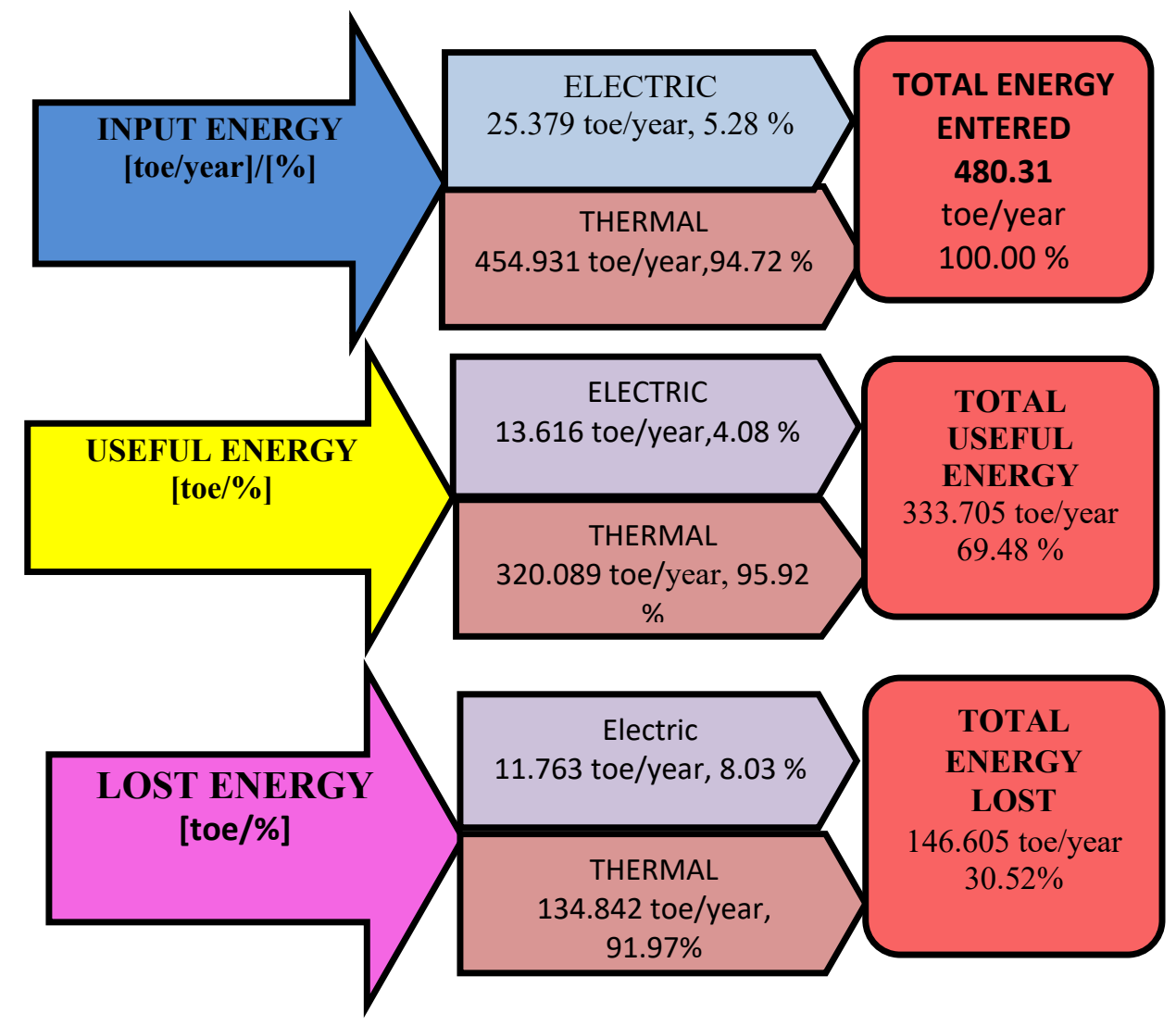

Fig. 3. Sankey diagram for the optimal complex annual energy balance.

Summary statement on data obtained for energy balance after implementation of the proposed measures to increase energy efficiency

- Total energy used annually $-\mathrm{E}_{\text {total }}=480.31$ toe

- Total thermal energy used annually - Total thermal $\mathrm{E}=454,931$ toe $(94.72 \%)$

- Total electricity used annually - $\mathrm{E}_{\text {total electricity }}=25,379$ toe $(5.28 \%)$

- Total energy utilized useful annually - $\mathrm{E}_{\text {total useful }}=333,705$ toe $(69.48 \%)$

- Total energy efficiency $-\eta$ total $=69.48 \%$

- Total annual useful heat recovered - E Useful thermal total $=320.089$ toe $(95.92 \%$ of the total useful energy)

- Thermoenergetic efficiency $-\eta$ thermoen. $=73.35 \%$

- Total utilized useful annual electricity - $\mathrm{E}$ total useful electricity $=13,616$ toe $(4.08 \%$ of total useful energy)

- Efficiency of electricity use - $\eta$ electroen. $=53.65 \%$

- Total energy lost annually $-\mathrm{E}_{\text {pierd.total }}=146605$ toe $(30.52 \%)$

- Total heat energy lost annually - It's heat loss. total $=134,842$ toe $(91.97 \%$ of total energy lost $)$

- Total electricity lost annually - It's electricity lost. total $=11,763$ toe $(8.03 \%$ of total energy lost $)$.

The increase in efficiencies, following the application of energy loss reduction measures, is represented in Figure 4. 


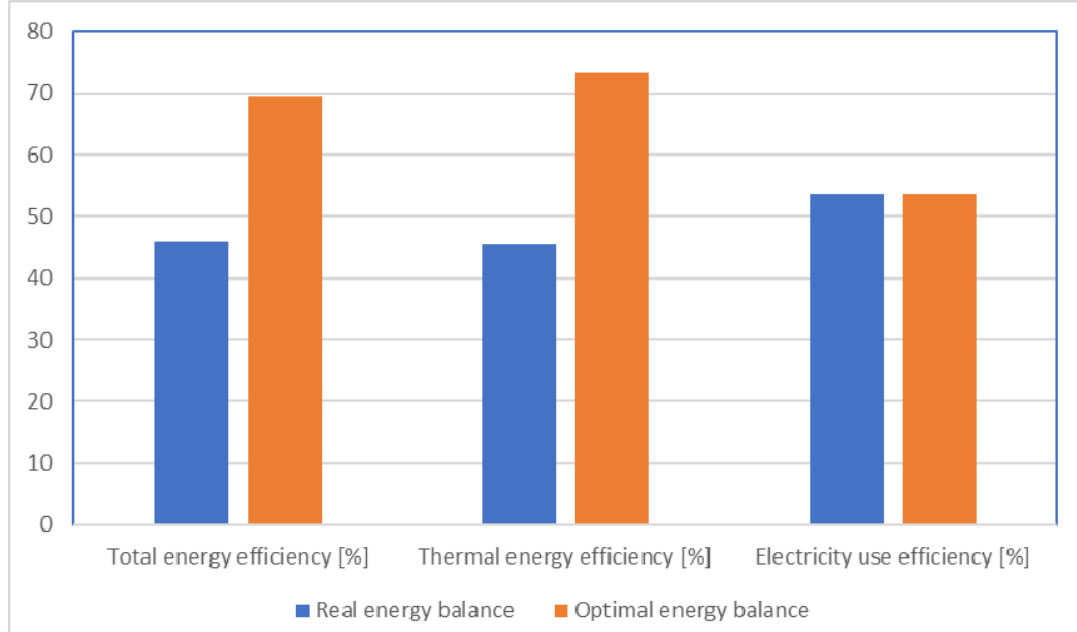

Fig.4. Variation of efficiencies, following the application of measures to reduce energy losses.

\section{Proposal of an aggregate indicator for estimating the sustainability of increasing energy efficiency}

The proposed indicator must quantify the synergistic effect of the whole:

- ENERGY USED - SYMBOL $\boldsymbol{E}$

- ECONOMIC COST - SYMBOL $\boldsymbol{C}$

- ENVIRONMENTAL IMPACT - SYMBOL $\boldsymbol{I}$

- SPECIFIC ENERGY CONSUMPTION - SYMBOL $\boldsymbol{S}$

Performing the following calculations:

- the sum of the energies used on the company outline, taken from the synthetic summary table of the complex energy balance for the company outline;

- the amount of energy savings achievable by applying the proposed measures;

- determination of the $\mathrm{CO}_{2}$ footprint related to the energy used;

- specific energy consumption,

- the values shown in Table 4 resulted.

Table 4. The values of the energy indicators after the application of the saving measure.

\begin{tabular}{|l|c|c|c|c|}
\hline \multicolumn{1}{|c|}{ Name } & \multicolumn{1}{|c|}{$\begin{array}{c}\text { Values after } \\
\text { single } \\
\text { Current } \\
\text { values } \\
\text { measures to } \\
\text { increase the } \\
\text { energy } \\
\text { efficiency }\end{array}$} & $\begin{array}{c}\text { Reduction } \\
\text { factor }\end{array}$ & $\begin{array}{c}\text { Discount } \\
\text { percentage }\end{array}$ \\
\hline ENERGY [MWh / year] & 8500 & 5585 & 0.657 & 34.3 \\
\hline $\begin{array}{l}\text { MEDIUM IMPACT } \\
\text { [tCO } / \text { /MWh] }\end{array}$ & 5960 & 3915 & 0.6568 & 34.32 \\
\hline ENERGY COST [thousand lei] & 4080 & 2681 & 0.6571 & 34.29 \\
\hline $\begin{array}{l}\text { SPECIFIC ENERGY } \\
\text { CONSUMPTION [MJ/ton] } 10\end{array}$ & 3250 & 2420 & 0.7446 & 25.54 \\
\hline
\end{tabular}


Based on the data mentioned in the table, a diagram was built (Figure 5) which cumulatively visualizes the synergistic effect of the specified quantities.

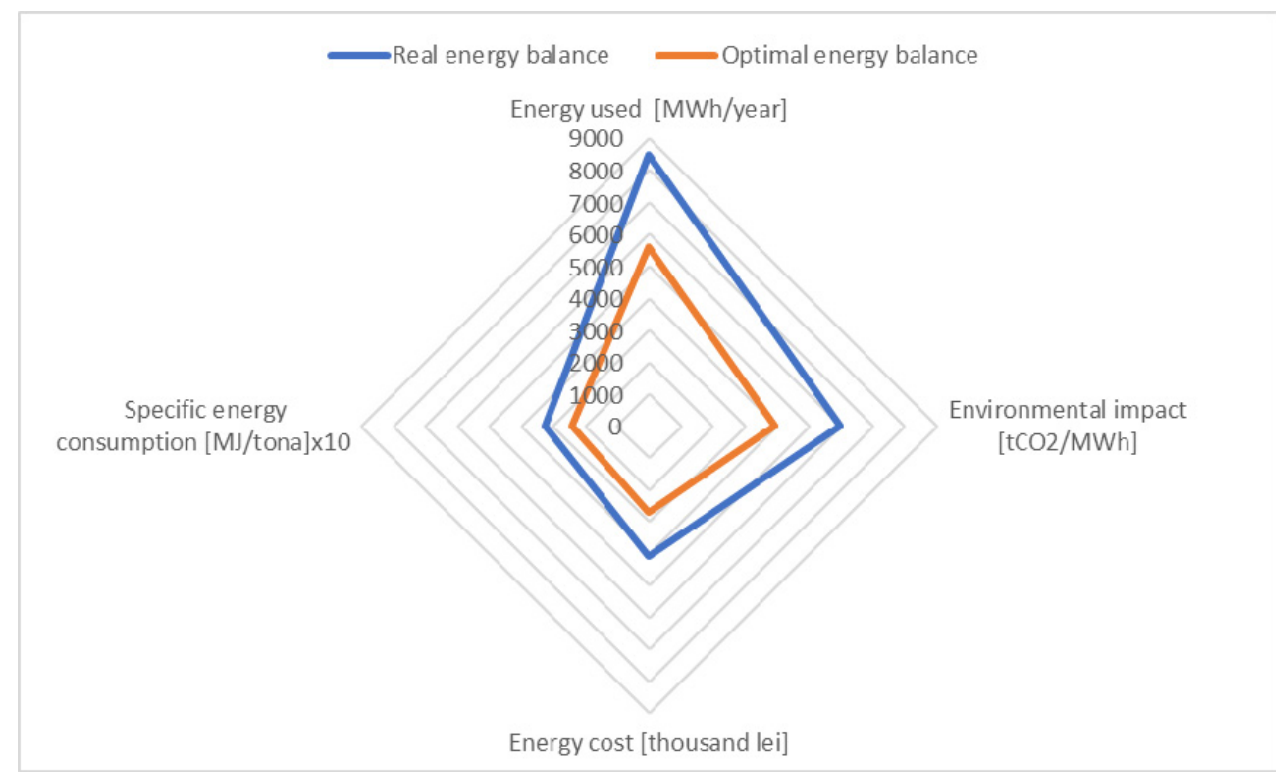

Fig.5. Diagram for calculating the integrated sustainability indicator.

By planning the two surfaces, the values were obtained:

$A_{\text {large }}=28.16 \mathrm{~cm}^{2} ; A_{\text {small }}=12.60 \mathrm{~cm}^{2}$, the surfaces quantifying the cumulative effect of the components: energy-environment-cost- specific consumption.

Assimilating the values of the surface areas with the indicator $\boldsymbol{E} \boldsymbol{C I S}$, it is possible to establish:

- the reduction factor of the $\boldsymbol{E} \boldsymbol{C I S}$ indicator by decreasing the energy used:

$$
\mathbf{F}_{\text {red. } E \text { CIS }}=\mathrm{A}_{\text {small }} / \mathrm{A}_{\text {large }}=0.328
$$

- percentage reduction of the $\boldsymbol{E} \boldsymbol{C I S}$ indicator by applying the proposed technicalorganizational measures:

$$
\mathbf{R}_{\text {proc } . \text { It } C I S}=\left[\left(\mathrm{A}_{\text {large }}-\mathrm{A}_{\text {small }}\right) / \mathrm{A}_{\text {sea }}\right] \times 100=55.26 \%
$$

\section{Conclusions}

The usefulness of the indicator consists in assembling some components of sustainable development: economic component, ecological responsibility, energy efficiency, also tangenting social solidarity by facilitating the obtaining of cheaper products.

The validation of the validity of the proposed indicator also results by comparing the value of the percentage reduction $\mathrm{R}_{\text {proc }}$. It is the CIS with the increase of the total energy efficiency, following the application of the proposed technical and organizational measures.

Total energy efficiency for the real balance (table 2 ) - real $\eta=45.78 \%$, and the total energy efficiency for the optimal balance (table 3 ) - optimal $\eta=69.48 \%$.

The percentage increase of the total energy efficiency, following the application of the proposed measures, amounts to $\Delta \eta=51.77 \%$, a value close to the percentage reduction of the proposed aggregate indicator. 
The major advantage of the indicator lies in the concentration of information of a different nature, offering decision makers a significant and useful comparison value, without going into the specific details of the diversity of the evaluated objective.

\section{References}

1. N. Kringos, T. Pauli, A. Schmets, A. Scarpas, Demonstration of a New Computational Model to Simulate Healing in Bitumen, Journal of the Association of Asphalt Paving Technologists. (2012)

2. *** https://documents.worldbank.org/en/publication/documents-reports

3. P. Bratu, Machines for communication routes, "Dunărea de Jos" University of Galaţi, (1994)

4. Y. Huang, R. Bird, O. Heidrich, Development of a life cycle assessment tool for construction and maintenance of asphalt pavements, Journal of Cleaner Production, pp. 283-296. (2009)

5. P. Zapata, J. Gambatese, Energy Consumption of Asphalt and Reinforced Concrete Pavement Materials and Construction", Journal of Infrastructure Systems, Vol 11, no.1, pp. 9-20, (2005)

6. S.I. Irimie, D.C. Petrilean, Consulting report on Thermoenergetic Analysis for "Drumuri Orăseneşti “ (Oradea, 2018) 